\title{
Association of vitamin $D$ receptor gene polymorphisms with metabolic syndrome: a case- control design of population-based cross-sectional study in North China
}

Yi Zhao ${ }^{1 \dagger}$, Sha Liao ${ }^{1 \dagger}$, Jun He${ }^{1}$, Yanan Jin ${ }^{1}$, Hailong Fu', Xiaoying Chen², Xuemin Fan ${ }^{3}$, Hongxia Xu', Xiuying Liu', Jing $\mathrm{Jin}^{4}$ and Yuhong Zhang ${ }^{1 *}$

\begin{abstract}
Background: Metabolic syndrome (MS) increases a risk of developing cardiovascular disease (CVD) and type 2 diabetes mellitus (T2DM). The Vitamin D Receptor gene (VDR) may be important for developing MS. The aim of this study is to investigate the correlation between the VDR gene polymorphisms and MS in North China.

Methods: A case-control study included 391 participants with MS according to the MS diagnostic criteria of International Diabetes Federation 2005 (IDF2005) and 400 controls was conducted on the basis of a cross sectional study which was performed from 2008 to 2012 in Ningxia Hui Autonomous Region, China. Anthropometric data, blood pressure and blood samples were collected in the field investigation. Blood biochemistry analyses were carried out in the laboratory. Two single-nucleotide polymorphisms (SNPs) in the VDR gene, Bsml (rs1544410 A > G) and Fokl (rs 2228570 C > T), were genotyped.

Results: The difference in the occurrence of genotypes in Bsml between individuals with MS and the control group was significant. Compared with genotype Bb/bb and allele b, genotype BB and allele B showed higher frequencies in MS cases than controls, which suggested they were risk factors. In addition, the genotype BB carriers with MS presented a higher waist circumference, while genotype FF for the Fokl polymorphism was correlated with lower BMI in subjects with MS.
\end{abstract}

Conclusion: Our study suggests that the VDR gene polymorphisms appear to be associated with MS in the Northern Chinese population. Allele B and BB genotype for Bsml are risk factors for MS. The Bsml polymorphism seems to influence waist circumference, while the Fokl polymorphism influence BMI in subjects with MS.

Keywords: Vitamin D Receptor gene, Polymorphisms, Metabolic syndrome

\section{Background}

Metabolic syndrome (MS) includes a variety of metabolic components in abnormal pathological state, which contains abnormal plasma glucose, dyslipidemia, high blood pressure, and high cholesterol [1]. Patients with MS have a greater risk of developing cardiovascular disease (CVD) and type 2 diabetes mellitus (T2DM) [2-4].

\footnotetext{
* Correspondence: zhabour@163.com

${ }^{\dagger}$ Equal contributors

${ }^{1}$ School of Public Health, Ningxia Medical University, 1160 Shengli Street, Yinchuan, Ningxia, P.R. China

Full list of author information is available at the end of the article
}

For the past few years, the prevalence of MS has been on the rise in adults globally, increasing from about $20 \%$ to $40 \%$ [5-8] in multiple groups of people, and is becoming a serious global health burden. Although insulin resistance [9] and central obesity [10] are considered to be its primary etiological factors, genetics undoubtedly plays an important role as well. In particular, genetic influence may be different among various ethnic groups [11].

The Vitamin D receptor (VDR) is a member of the steroid hormone receptor family that acts as a transcriptional activator of many genes. The DNA polymorphisms that

\section{Biomed Central}

(c) 2014 Zhao et al.; licensee BioMed Central Ltd. This is an Open Access article distributed under the terms of the Creative Commons Attribution License (http://creativecommons.org/licenses/by/4.0), which permits unrestricted use, distribution, and reproduction in any medium, provided the original work is properly credited. The Creative Commons Public Domain Dedication waiver (http://creativecommons.org/publicdomain/zero/1.0/) applies to the data made available in this article, unless otherwise stated. 
have been often reported for the VDR gene are (described in both restriction sites and dbSNP info): BsmI (rs1544410 $\mathrm{A}>\mathrm{G}$ ), FokI (rs $2228570 \mathrm{C}>\mathrm{T}$ ), TaqI (rs731236 T $>\mathrm{C}$ ), and ApaI (rs $7975232 \mathrm{C}>\mathrm{T}$ ). In past years, many studies have found that these polymorphisms are related to bone mineral density(BMD) [12], calcium metabolism [13], tuberculosis, hepatitis [14] and cancer $[15,16]$. Additionally, some of these polymorphisms have been recently identified to be associated with type 1 diabetes [17], T2DM [18], and insulin secretion [19].

Although the molecular mechanisms of VDR in components of MS remain unclear, a relationship between $25(\mathrm{OH}) \mathrm{D}_{3}$ and the disorders of MS has been previously demonstrated [20-23]. Studies have also discussed VDR gene polymorphisms for associations with the components of MS, which suggest that two major VDR gene polymorphisms (BsmI and FokI) seemed to influence BMI, insulin resistance, and serum HDL cholesterol $[24,25]$. However, little is known about the role of VDR gene polymorphisms in MS for Chinese population.

Therefore, we suppose the two single-nucleotide polymorphisms (SNPs), BsmI (rs1544410 A > G) and FokI (rs $2228570 \mathrm{C}>\mathrm{T}$ ), of the VDR gene intricately affect the development of MS. This study was designed to determine the contribution of VDR polymorphisms to MS in a population from North China.

\section{Materials and methods \\ Participants}

A cross-sectional study was conducted from 2008 to 2012 in Guyuan County, Qingtongxia County and Pingluo County, of Ningxia Hui Autonomous Region, China. Stratified cluster sampling was applied to select two villages (one Hui ethnic village and one Han ethnic village) in each county, totaling six villages. During the study period, 4614 subjects aged 24-75 were interviewed with a questionnaire, followed by anthropometric measurements (height, weight, waist circumference), and blood pressure determination. Pregnant or breastfeeding women, patients with severe mental disease and other serious illness were excluded from the study. The subjects enrolled did not report to have chronic viral infection, cold or flu, acute respiratory infection, or any type of surgery in the week preceding the study. Meanwhile, 2615 participants had blood drawn via venipuncture for laboratory measurements, and finally 1169 blood samples were selected for genotyping by mechanical sampling $(\mathrm{k}=1)$. Based on diagnostic criteria (International Diabetes Federation IDF-2005), 391 cases with MS and 400 controls were selected from the same population to conduct the case-control study. The study protocol had been approved by the Medical Ethics Review Committee of Ningxia Medical University. All participants signed the consents on enrollment after they received written and verbal information about the study.

All participants were interviewed by trained persons with a standard closed-ended questionnaire. The contents of the questionnaire included general demographic characteristics, blood pressure, blood lipid, blood sugar, smoking, physical activity status, drinking and related diseases (including hypertension, coronary heart disease, stroke and diabetes medical history and family history, individual treatment, etc.).

\section{Anthropometric measurements and blood pressure}

Standing height was measured using a portable ruler. Body weight was also measured using a weight scale (Omron, China). All measurements were performed by well-trained investigators. The reading of measurements was accurate within $0.1 \mathrm{~cm}$ or $0.1 \mathrm{~kg}$, and the average of the two collected measures was recorded for further analysis. Body mass index (BMI) was calculated as $\mathrm{kg} / \mathrm{m}^{2}$. Obesity was defined as $\mathrm{BMI} \geq 30$. Arterial blood pressure was measured three times in sitting position using an electronic sphygmomanometer (Omron-HEM 7301-IT, China). All participants were at rest for at least 30 minutes before the measurement was collected. Patients with average blood pressures $\geq 140 / 90 \mathrm{mmHg}$ or taking antihypertensive medication in 2 weeks were classified as being hypertensive.

\section{Blood biochemistry analyses}

Blood samples were drawn from the antecubital vein at the hours of 6 to $8 \mathrm{AM}$, after at least 10 hours of fasting and avoidance of alcohol. Two sets of fasting blood samples were collected separately from each subject in sodium fluoride potassium oxalate tubes (for glucose) and lithium heparin vacuum tubes (for lipids).The latter collections were then centrifuged and kept at $-80^{\circ} \mathrm{C}$ until analysis. Fasting glucose was immediately determined by One Touch Ultra 2 (LifeScan, USA). Serum levels of HDL- cholesterol, LDL- cholesterol, and triglycerides were measured by enzymatic assay (CHOD-PAP, Roche Diagnostics $\mathrm{GmbH}$ ). All analyses were carried out through an automatic biochemical analyzer (COBASE 501, Roche Diagnostics $\mathrm{GmbH}$ ). Subjects were further divided into two groups, cases with MS and controls without MS, according to the IDF definition. For a subject to be defined as having MS, they must have: Central obesity (waist circumference $\geq 90 \mathrm{~cm}$ in males, $\geq 80 \mathrm{~cm}$ in females, or BMI is $>30 \mathrm{~kg} / \mathrm{m}^{2}$ ) along with any two of the following four factors: triglycerides $\geq 150 \mathrm{mg} / \mathrm{dL}$ $(1.7 \mathrm{mmol} / \mathrm{L}) ; \mathrm{HDL}$-cholesterol $<40 \mathrm{mg} / \mathrm{dl}(1.03 \mathrm{mmol} / \mathrm{L})$ in males, $<50 \mathrm{mg} / \mathrm{dL}(1.29 \mathrm{mmol} / \mathrm{L})$ in females; blood pressure, systolic $\mathrm{BP} \geq 130$ or diastolic $\mathrm{BP} \geq 85 \mathrm{mmHg}$; fasting glucose $\geq 5.6 \mathrm{mmol} / \mathrm{L}(100 \mathrm{mg} / \mathrm{dl})[1]$. 


\section{Genotyping}

Genomic DNA was extracted from the whole blood with the SE Blood DNA Kit (OMEGA, USA). After extraction, 30 samples of the extracted material were randomly selected for validation by agarose gel electrophoresis. SNP genotyping of BsmI and FokI in the VDR gene was performed using a technology known as SNPscan ${ }^{\text {тM }}$ [26-28](Genesky Biotechnologies, China). SNPscan ${ }^{\text {тм }}$ is a patent technology and developed on double ligation and multiplex fluorescence PCR with high genotyping accuracy (>99.9\%) and call rate (>98\%). Specifically, highly multiple ligation products in different length were generated on account of high specificity of the ligase reaction. Meanwhile, the ligation probes and templates were further lengthened through double ligation. With blue fluorescent dye modified universal primers, ligation products were amplified by Thermal Cycler (ABI, USA) and then detected through fluorescent capillary electrophoresis. Finally, GeneMapper (Life Technologies) software was used to read the data.

\section{Statistical analysis}

Statistical analysis was conducted using SPSS statistical software (version 14.0 SPSS Corp, College Station, TX) and descriptive data were presented by mean and standard deviation. The Kolmogorov-Smirnov test was used to analyze normality of the distribution of each variable. Comparisons between any two groups were performed using independent t-tests. Chi-square analysis was applied to examine the variation of sex, genotype and gene frequency in different MS groups. Chi-square analysis was also used to test Hardy-Weinberg equilibrium (HWE) for the genotypes in all groups of subjects. ANOVA analysis was used to analyze clinical variables in different genotypes. Odds ratios (ORs) and their 95\% confidence interval (CI) were computed for the risk alleles from logistic regression analysis. Statistical significance was set at $\mathrm{P}<0.05$.

\section{Results}

\section{General characteristics and components of MS}

Characteristics of the subjects with and without MS are shown in Table 1. In our study, the mean age of the 391 participants with MS was $53( \pm 11)$ years, and the mean age of 400 controls was $53( \pm 11)$ years. Compared with the controls, BMI, waist circumference, blood pressure, fasting glucose, and triglycerides were significantly higher in individuals with MS, while HDL cholesterol was lower. Both VDR BsmI and FokI genotypic distributions in controls were in Hardy-Weinberg equilibrium $(P, 0.762$ and 0.376 , respectively) (Table 2 ).

The distribution of VDR Bsml and Fokl polymorphisms As shown in Table 3, both genotypic and allelic frequencies of VDR BsmI and FokI polymorphisms were presented for
Table 1 Population Characteristics and components of MS

\begin{tabular}{cccc}
\hline & MS & Control & P-value \\
\hline Male/Female, $n$ & $99 / 292$ & $100 / 300$ & 0.917 \\
Age & $53.37 \pm 10.99$ & $53.73 \pm 11.08$ & 0.997 \\
Height $(\mathrm{cm})$ & $159.09 \pm 8.11$ & $157.73 \pm 7.34$ & 0.018 \\
Weight(kg) & $66.19 \pm 10.15$ & $56.09 \pm 7.90$ & $<0.001$ \\
BMl & $26.09 \pm 2.97$ & $22.53 \pm 2.72$ & $<0.001$ \\
WC(cm) & $89.70 \pm 6.63$ & $79.11 \pm 7.47$ & $<0.001$ \\
BPS(mmHg) & $136.88 \pm 20.38$ & $124.87 \pm 18.29$ & $<0.001$ \\
BPD(mmHg) & $84.13 \pm 11.55$ & $77.19 \pm 11.01$ & $<0.001$ \\
FBG $(\mathrm{mmol} / \mathrm{L})$ & $6.15 \pm 1.31$ & $5.58 \pm 0.83$ & $<0.001$ \\
TG(mmol/L) & $2.07 \pm 1.19$ & $1.30 \pm 1.16$ & $<0.001$ \\
HDL-C(mmol/L) & $1.28 \pm 0.38$ & $1.48 \pm 0.34$ & $<0.001$ \\
\hline
\end{tabular}

WC, Waist circumference; BPS, Systolic blood pressure; BPD, Diastolic blood pressure; FBG, fasting blood-glucose; TG, triglycerides; HDL-C, HDL- cholesterol.

participants with or without MS. Genotypes of BsmI and FokI are normally expressed as dominant homozygous genotype "BB, FF", heterozygous genotype "Bb, Ff", and recessive homozygous genotype "bb, ff". There were differences in genotypes and gene frequencies of VDR BsmI between the MS cases and controls, with P-values of 0.011 and 0.03 respectively. Frequency of genotype $\mathrm{BB}$ and $\mathrm{Bb}$ was significantly different between individuals with MS and without MS, after comparing all of the three genotypes with each other $\left(\mathrm{X}^{2}=7.022, \mathrm{P}=0.008\right)$. However, there was no difference in FokI polymorphism.

\section{VDR polymorphisms and MS risk}

The difference in the occurrence of the genotypes in BsmI between individuals with MS and the control group was significant (Ptrend $=0.02$ ). The frequencies of genotype $\mathrm{BB}$ and combined $\mathrm{Bb} / \mathrm{bb}$ in individuals with MS were $89 \%$ and $11 \%$ respectively, in the control group were $82 \%$ and $18 \%$ respectively, which suggested that the genotype $\mathrm{BB}$ was a risk factor $(P=0.006$; $\mathrm{OR}=1.771$; $95 \%$ $\mathrm{CI}, 1.179-2.661)$. Compared with genotype $\mathrm{BB}$, genotype $\mathrm{Bb}$ was likely to be a protective factor $(P=0.009$; $\mathrm{OR}=0.575$; 95\% CI, 0.381-0.869). The incidences of B and b alleles for the BsmI polymorphism in the two group were statistically significant (allele $B$ vs. $b ; P=0.005$ ), which indicated allele $b$

Table 2 Hardy-Weinberg equilibrium of control group

\begin{tabular}{|c|c|c|c|c|c|}
\hline \multicolumn{2}{|c|}{ Genotype } & \multirow{2}{*}{$\begin{array}{c}\text { Predictive value } \\
328.52\end{array}$} & \multirow{2}{*}{$\begin{array}{c}\text { Observed value } \\
328\end{array}$} & \multirow{2}{*}{$\frac{x^{2}}{0.092}$} & \multirow{2}{*}{$\frac{P \text {-value }}{0.762}$} \\
\hline Bsml & CC & & & & \\
\hline & $C T$ & 67.97 & 69 & & \\
\hline & $\pi$ & 3.52 & 3 & & \\
\hline \multirow[t]{3}{*}{ Fokl } & AA & 84.39 & 80 & 0.783 & 0.376 \\
\hline & $A G$ & 198.22 & 207 & & \\
\hline & GG & 116.39 & 112 & & \\
\hline
\end{tabular}


Table 3 Genotypes and gene frequencies

\begin{tabular}{|c|c|c|c|c|c|c|c|c|c|c|}
\hline & \multicolumn{5}{|c|}{ Bsml } & \multicolumn{5}{|c|}{ Fokl } \\
\hline & BB & $\mathrm{Bb}$ & bb & B & b & $\mathrm{FF}$ & $\mathrm{Ff}$ & ff & $F$ & $f$ \\
\hline MS, $\mathbf{n}$ & 347 & 42 & 1 & 736 & 44 & 75 & 184 & 132 & 334 & 448 \\
\hline Control, n & 328 & 69 & 3 & 725 & 75 & 80 & 207 & 112 & 367 & 431 \\
\hline$x^{2}$ & \multicolumn{5}{|c|}{9.016} & \multicolumn{3}{|c|}{3.073} & \multicolumn{2}{|c|}{1.720} \\
\hline$P$-value & \multicolumn{3}{|c|}{$0.011^{*}$} & \multicolumn{2}{|c|}{0.03} & \multicolumn{3}{|c|}{0.215} & \multicolumn{2}{|c|}{0.19} \\
\hline
\end{tabular}

*Fisher's Exact Test; BB/FF normally show dominant homozygous genotype; $\mathrm{Bb} / \mathrm{Ff}$ show heterozygous genotype; bb/ff show recessive homozygous genotype.

could be a protective factor. However, it seemed no significant evidence to be risk factors or protective factors to FokI polymorphism in individuals with MS (Table 4).

Moreover, the genotypes of BsmI and FokI were combined and generated as 9 new genotypes like BBFF to analyze the cumulative effect of the polymorphisms, as shown in Table 4. But there were no significant differences in the risk of MS (Ptrend =0.187).

Table 4 Fokl and Bsml polymorphisms and MS risk

\begin{tabular}{|c|c|c|c|c|c|}
\hline Genotype & MS n(\%) & Control n(\%) & $P$-value & OR & $95 \% \mathrm{Cl}$ \\
\hline \multicolumn{6}{|l|}{$\mathrm{Bsml}^{\mathrm{a}}$} \\
\hline $\mathrm{BB}(\mathrm{CC})$ & $347(89.0)$ & $328(82.0)$ & & 1 & \\
\hline $\mathrm{Bb}(\mathrm{CT})$ & $42(10.7)$ & $69(17.3)$ & 0.009 & 0.575 & $0.381-0.869$ \\
\hline $\mathrm{bb}(\mathrm{TT})$ & $1(0.3)$ & $3(0.7)$ & 0.318 & 0.315 & $0.033-3.044$ \\
\hline $\mathrm{Bb}+\mathrm{bb}$ & 43 & 72 & & 1 & \\
\hline $\mathrm{BB}$ & 347 & 328 & 0.006 & 1.771 & $1.179-2.661$ \\
\hline B & 736(94.4) & 725(90.6) & & 1 & \\
\hline$b$ & $44(5.6)$ & 75(9.4) & 0.005 & 0.578 & $0.393-0.850$ \\
\hline \multicolumn{6}{|l|}{ Fokl $^{b}$} \\
\hline $\mathrm{FF}(\mathrm{AA})$ & 75(19.2) & $80(20.0)$ & & 1 & \\
\hline $\mathrm{Ff}(\mathrm{AG})$ & 184(47.1) & 207(58.9) & 0.779 & 0.948 & $0.653-1.376$ \\
\hline $\mathrm{ff}(\mathrm{GG})$ & 132(33.7) & $112(28.1)$ & 0.266 & 1.257 & 0.840-1.882 \\
\hline $\mathrm{Ff}+\mathrm{ff}$ & 316 & 319 & & 1 & \\
\hline $\mathrm{FF}$ & 75 & 80 & 0.759 & 0.946 & $0.666-1.345$ \\
\hline$F$ & $334(42.7)$ & $367(46.0)$ & & 1 & \\
\hline f & $448(57.3)$ & $431(54.0)$ & 0.190 & 1.142 & 0.936-1.393 \\
\hline $\mathrm{BBFF}^{\mathrm{C}}$ & 69 & 68 & & 1 & \\
\hline BBFf & 164 & 174 & 0.761 & 0.929 & $0.624-1.382$ \\
\hline BBff & 114 & 85 & 0.211 & 1.322 & $0.854-2.046$ \\
\hline $\mathrm{BbFF}$ & 5 & 11 & 0.156 & 0.448 & $0.148-1.358$ \\
\hline $\mathrm{BbFf}$ & 19 & 32 & 0.111 & 0.585 & $0.303-1.131$ \\
\hline Bbff & 18 & 26 & 0.276 & 0.682 & $0.343-1.358$ \\
\hline bbFF & 0 & 1 & 1.000 & 0.000 & 0.000 \\
\hline $\mathrm{bbFf}$ & 1 & 1 & 0.992 & 0.986 & $0.060-16.077$ \\
\hline Bbff & 0 & 1 & 1.000 & 0.000 & 0.000 \\
\hline
\end{tabular}

${ }^{\mathrm{a}} P$ trend $=0.02 ;{ }^{\mathrm{b}}$ Ptrend $=0.216 ;{ }^{\mathrm{C}} \mathrm{P}$ trend $=0.187 ; \mathrm{BB} / \mathrm{FF}$ normally show dominant homozygous genotype; $\mathrm{Bb} / \mathrm{Ff}$ show heterozygous genotype; $\mathrm{bb} / \mathrm{ff}$ show recessive homozygous genotype.
The associations of VDR gene polymorphisms with the components of MS

Table 5 presented the distribution of some clinical variables according to the genotypes observed in individuals with MS and without MS. Because of the limited frequencies of genotype bb in the VDR BsmI polymorphism, we combined $\mathrm{Bb}$ and $\mathrm{bb}$ genotype as a group. For the VDR BsmI variant, individuals with MS carrying BB genotype presented a higher waist circumference than individuals with $\mathrm{Bb}+\mathrm{bb}$ genotype, whilst genotype $\mathrm{BB}$ was associated with higher waist circumference and BMI in individuals without MS than seen in others. Additionally, the presence of FF genotype for the FokI polymorphism was associated with lower BMI than that with $\mathrm{Ff} / \mathrm{ff}$ genotype in individuals with MS. In addition, to the individuals without MS, higher systolic blood pressure was seen in subjects with Ff genotype than that with $\mathrm{ff}$ genotype, and subjects with genotype FF/Ff presented a higher diastolic blood pressure than individuals with $\mathrm{ff}$ genotype. Moreover, the values of the remaining variables were very similar among all subjects for both VDR BsmI and FokI polymorphisms.

\section{Discussion}

The results showed that VDR polymorphisms may influence the emergence of MS. The VDR BsmI (rs1544410 A $>$ G) polymorphism appeared to associate with MS. Specifically, allele B and genotype of BB in BsmI were associated with $\mathrm{MS}$, while allele $\mathrm{b}$ and genotype $\mathrm{Bb}$ seemed to play a protective role. The role of genotype bb was unclear, because of its limited frequency. When discussed VDR gene polymorphisms with the components of MS, we found the genotype BB carriers with MS presented a higher waist circumference. In addition, genotype FF for the VDR FokI (rs2228570 C > T) polymorphism was correlated with lower BMI in MS. Our findings were different with previous researches which demonstrated the VDR FokI polymorphism was related with triglycerides and HDL-cholesterol levels [25].

A few studies have demonstrated that VDR polymorphisms were related to obesity, diabetes, insulin sensitivity and insulin secretion $[17,19,29]$. VDR BsmI and FokI polymorphisms have been previously reported to be associated with anthropometric and biochemical parameters describing MS. Trzmiel et al. (2008) found that VDR BsmI polymorphism seemed to influence BMI, while the FokI VDR polymorphism appeared to affect insulin sensitivity and serum HDL cholesterol in men [24]. However, Lwow et al. (2008) indicated that VDR BsmI polymorphism did not seem to predispose postmenopausal women to obesity and insulin resistance, but the genotype $\mathrm{BB}$ was connected with dyslipidemia [30]. Frey et al. (2003) did not find evidence for the association of VDR polymorphisms with glycemia either [31]. Results of these study seemed to conflict with the pleiotropic effect of the VDR gene 
Table 5 Fokl and Bsml polymorphisms and MS components

\begin{tabular}{|c|c|c|c|c|c|c|c|}
\hline & \multicolumn{2}{|c|}{ Bsml (rs1544410 A > G) } & \multirow[t]{2}{*}{$P$} & \multicolumn{3}{|c|}{ Fokl (rs 2228570 C > T) } & \multirow[t]{2}{*}{$P$} \\
\hline & BB & $B b+b b$ & & $\mathrm{FF}$ & $\mathrm{Ff}$ & $\mathrm{ff}$ & \\
\hline BMl & $26.1 \pm 3.1$ & $25.7 \pm 2.2$ & 0.396 & $25.1 \pm 2.5^{a}$ & $26.3 \pm 3.1$ & $26.4 \pm 2.9$ & 0.005 \\
\hline$W C(\mathrm{~cm})$ & $90 \pm 6.6$ & $87.6 \pm 6.3$ & 0.025 & $88.7 \pm 5.5$ & $89.7 \pm 7$ & $90 \pm 6.6$ & 0.284 \\
\hline $\mathrm{BPS}(\mathrm{mmHg})$ & $136.4 \pm 19.8$ & $141.9 \pm 22.7$ & 0.096 & $135.9 \pm 20$ & $137.5 \pm 20.6$ & $136.6 \pm 20.4$ & 0.829 \\
\hline $\mathrm{BPD}(\mathrm{mmHg})$ & $84.1 \pm 11.4$ & $85 \pm 12.5$ & 0.625 & $84 \pm 11.8$ & $84.8 \pm 11.3$ & $83.2 \pm 11.8$ & 0.438 \\
\hline $\mathrm{FBG}(\mathrm{mmol} / \mathrm{L})$ & $6.1 \pm 1.2$ & $6.4 \pm 2.2$ & 0.163 & $6.2 \pm 1.6$ & $6.1 \pm 1$ & $6.2 \pm 1.5$ & 0.496 \\
\hline $\mathrm{TG}(\mathrm{mmol} / \mathrm{L})$ & $2.1 \pm 1.2$ & $2 \pm 1.2$ & 0.788 & $2.1 \pm 0.9$ & $2.1 \pm 1.3$ & $2 \pm 1.2$ & 0.821 \\
\hline $\mathrm{HDL}-\mathrm{C}(\mathrm{mmol} / \mathrm{L})$ & $1.3 \pm 0.4$ & $1.4 \pm 0.3$ & 0.177 & $1.2 \pm 0.3$ & $1.3 \pm 0.3$ & $1.3 \pm 0.5$ & 0.077 \\
\hline Control & $22.7 \pm 2.8$ & $22 \pm 2.4$ & 0.030 & $22.5 \pm 2.9$ & $22.5 \pm 2.6$ & $22.5 \pm 2.8$ & 0.995 \\
\hline WC(cm) & $79.7 \pm 7.6$ & $76.3 \pm 6.1$ & 0.000 & $78.7 \pm 8$ & $79.2 \pm 6.5$ & $79.2 \pm 8.7$ & 0.849 \\
\hline $\mathrm{BPS}(\mathrm{mmHg})$ & $124.9 \pm 18.3$ & $124.9 \pm 18.3$ & 0.985 & $124.9 \pm 18.6$ & $126.8 \pm 19.3^{b}$ & $121.5 \pm 15.6$ & 0.045 \\
\hline $\mathrm{BPD}(\mathrm{mmHg})$ & $77.2 \pm 11.1$ & $77.1 \pm 10.8$ & 0.939 & $78.2 \pm 10.5$ & $78.1 \pm 11.8$ & $74.9 \pm 9.4^{a}$ & 0.031 \\
\hline $\mathrm{FBG}(\mathrm{mmol} / \mathrm{L})$ & $5.6 \pm 0.9$ & $5.6 \pm 0.5$ & 0.727 & $5.5 \pm 0.8$ & $5.7 \pm 1$ & $5.5 \pm 0.5$ & 0.118 \\
\hline $\mathrm{TG}(\mathrm{mmol} / \mathrm{L})$ & $1.3 \pm 1.2$ & $1.2 \pm 0.6$ & 0.254 & $1.3 \pm 0.6$ & $1.3 \pm 1.5$ & $1.2 \pm 0.6$ & 0.789 \\
\hline $\mathrm{HDL}-\mathrm{C}(\mathrm{mmol} / \mathrm{L})$ & $1.5 \pm 0.3$ & $1.5 \pm 0.3$ & 0.227 & $1.4 \pm 0.3$ & $1.5 \pm 0.3$ & $1.5 \pm 0.3$ & 0.596 \\
\hline
\end{tabular}

${ }^{\mathrm{a}}$ significant for the genotype Ff/ff; ${ }^{\mathrm{b}}$ significant for the genotype ff.

in individuals with MS, and this result was not found in other populations [32]. Moreover, interactions in circulating glucose, triglyceride, cholesterol and insulin levels were not well explained [33,34]. For this reason, whether these differences come from ethnic variations or interactions in components of MS still needs further exploration, and we should not focus on the disorders in MS separately.

The VDR gene is not a main influencing factor to the variability of circulating levels of vitamin $\mathrm{D}$, according to genome-wide association (GWA) studies $[17,35,36]$. However, it is clear that the VDR gene plays a primary role in the pleiotropic actions of $1,25(\mathrm{OH})_{2} \mathrm{D}_{3}$ [37] and in insulin secretion [19,38]. Serum 25-hydroxyvitamin D levels is inversely related to percentage body fat content in healthy women [20] and incident hypertension [21]. Furthermore, McKeown et al. (2011) found that the predicted 25hydroxyvitamin D score might be an important determinant for change in fasting plasma glucose concentration in the Framingham offspring study [22]. Unfortunately, our study did not include serum 25-hydroxyvitamin D, but we could assume that serum 25-hydroxyvitamin D is the focus leading metabolic disorders if the interactions we discussed above were taken into consideration.

\section{Conclusion}

This study revealed a significant association of VDR BsmI polymorphism with MS in the Northern Chinese population. Allele B and genotype BB for BsmI are risk factors for MS. The BsmI polymorphism seemed to influence waist circumference, while the FokI polymorphism influence BMI in subjects with MS. Thus, we propose that the BsmI and FokI polymorphisms of VDR are potential prognostic variables which may predict the risk of developing MS. Even so, further examination should be carried out on large population. Also, genome wide association studies are still needed to evaluate the direct effect of these polymorphisms on MS.

\section{Abbreviations \\ MS: Metabolic syndrome; VDR: Vitamin D Receptor gene; CVD: Cardiovascular disease; T2DM: Type 2 diabetes mellitus; IDF2005: International Diabetes Federation 2005; SNPs: Single-nucleotide polymorphisms; BMD: Bone mineral density; BMI: Body mass index; WC: Waist circumference; BPS: Systolic blood pressure; BPD: Diastolic blood pressure; FBG: Fasting blood-glucose; \\ TG: Triglycerides; HWE: Hardy-Weinberg equilibrium; Cl: Confidence interval; GWA: Genome-wide association.}

\section{Competing interests}

The authors declare that they have no competing interests.

\section{Authors' contributions}

Conception of research idea and Secure funding: $Y Z, Y H Z ;$ Study Design: $Y Z$, YHZ,SL; Implementation (training; Data collection): SL, YZ, JH, YNJ, HLF, XYC, $X M F, J J, H X X, X Y L$; Study coordination and management: $Y Z, Y H Z$; Data management: YZ, ZYH; Data analysis and drafting paper: SL, YZ. All authors read and approved the final manuscript.

\section{Authors' information}

Yi Zhao and Sha Liao Co-first authors.

\section{Acknowledgements}

This study was supported by Natural Science Foundation of China (No.81160358). The authors wish to thank: doctors of each Rural Hospital for their administrative support during the performing stage of the study and all interviewees who agreed to participate in the study.

\section{Author details}

${ }^{1}$ School of Public Health, Ningxia Medical University, 1160 Shengli Street, Yinchuan, Ningxia, P.R. China. ${ }^{2}$ Centers for Disease Control and Prevention in Ningxia, 180 Baohu Road, Yinchuan, Ningxia, P.R. China. ${ }^{3}$ Department of Clinic Administrations, Ningxia People's Hospital, 301 Zhengyuan Street, Jingfeng District, 750004 Yinchuan, Ningxia, PR of China. ${ }^{4}$ Affiliated Hospital of Ningxia Medical University, 804 Shengli Street, Yinchuan, Ningxia, P.R. China. 
Received: 10 May 2014 Accepted: 5 August 2014

Published: 9 August 2014

\section{References}

1. Alberti KGM, Zimmet P, Shaw J: The metabolic syndrome-a new worldwide definition[J]. Lancet 2005, 366(9491):1059-1062.

2. Ford ES: Risks for all-cause mortality, cardiovascular disease, and diabetes associated with the metabolic syndrome: a summary of the evidence[J]. Diabetes Care 2005, 28(7):1769-1778.

3. Gami AS, Witt BJ, Howard DE, Erwin PJ, Gami LA, Somers VK, Montori VM: Metabolic syndrome and risk of incident cardiovascular events and DeathA systematic review and meta-analysis of longitudinal studies[]]. J Am Coll Cardiol 2007, 49(4):403-414.

4. Wilson PWF, D'Agostino RB, Parise H, Sullivan L, Meigs JB: Metabolic syndrome as a precursor of cardiovascular disease and type 2 diabetes mellitus[J]. Circulation 2005, 112(20):3066-3072.

5. Ford ES, Giles WH, Dietz WH: Prevalence of the metabolic syndrome among us adults: Findings from the third national health and nutrition examination survey[J]. JAMA 2002, 287(3):356-359.

6. Gu D, Reynolds K, Wu X, Chen J, Duan X, Reynolds RF, Whelton PK, He J: Prevalence of the metabolic syndrome and overweight among adults in China[J]. Lancet 2005, 365(9468):1398-1405.

7. Ramli AS, Daher AM, Nor Ashikin MN, Mat Nasir N, Ng KK, Miskan M, Ambigga KS, Ariffin F, Mazapuspavina MY, Abdul Razak S, Abdul Hamid H, Abd Majid F, Abu Bakar N, Nawawi H, Yusoff K: JIS definition identified more Malaysian adults with metabolic syndrome compared to the NCEP-ATP III and IDF criteria[J]. Biomed Res Int 2013, $2013: 760963$.

8. $Y i Z$, Jing J, Xiuying $L$, Hongxia $X$, Jianjun $Y$, Yuhong $Z$ : Prevalence of the metabolic syndrome among rural original adults in NingXia, china[J]. BMC Public Health 2010, 10(1):140.

9. Hu G, Qiao Q, Tuomilehto J, Eliasson M, Feskens EJ, Pyörälä K: Plasma insulin and cardiovascular mortality in non-diabetic European men and women: a meta-analysis of data from eleven prospective studies[]]. Diabetologia 2004, 47(7):1245.

10. Després J-P, Lemieux I: Abdominal obesity and metabolic syndrome[J]. Nature 2006, 444(7121):881-887.

11. Oh J-Y, Barrett-Connor E: Association between vitamin D receptor polymorphism and type 2 diabetes or metabolic syndrome in community-dwelling older adults: the rancho Bernardo study[J]. Metab Clin Exp 2002, 51(3):356-359.

12. Cooper GS, Umbach DM: Are vitamin D receptor polymorphisms associated with bone mineral density? A meta-analysis[J]. J Bone Miner Res 1996, 11(12):1841-1849.

13. Li YC, Bolt MJ, Cao LP, Sitrin MD: Effects of vitamin D receptor inactivation on the expression of calbindins and calcium metabolism[J]. Am J Physiol-Endocrinol Metabolism 2001, 281(3):E558-E564

14. Bellamy R, Ruwende C, Corrah T, McAdam KP, Thursz M, Whittle HC, Hill AV: Tuberculosis and chronic hepatitis $B$ virus infection in Africans and variation in the vitamin D receptor gene[J]. J Infect Dis 1999, 179(3):721-724.

15. John EM, Schwartz GG, Koo J, Van Den Berg D, Ingles SA: Sun exposure, vitamin $\mathrm{D}$ receptor gene polymorphisms, and risk of advanced prostate cancer[J]. Cancer Res 2005, 65(12):5470-5479.

16. Li L, Wu B, Yang L, Yin G, Wei W, Sui S, Liu J: Association of vitamin D receptor gene polymorphisms with pancreatic cancer: A pilot study in a North China Population[J]. Oncol Lett 2013, 5(5):1731-1735.

17. Cooper JD, Smyth DJ, Walker NM, Stevens H, Burren OS, Wallace C, Greissl C, Ramos-Lopez E, Hyppönen E, Dunger DB, Spector TD, Ouwehand WH, Wang TJ, Badenhoop K, Todd JA: Inherited variation in vitamin $D$ genes is associated with predisposition to autoimmune disease type 1 diabetes[]]. Diabetes 2011, 60(5):1624-1631.

18. Li L, Wu B, Liu JY, Yang LB: Vitamin D Receptor Gene Polymorphisms and Type 2 Diabetes: A Meta-analysis[J]. Arch Med Res 2013, 44(3):235-241.

19. Hitman GA, Mannan N, McDermott MF, Aganna E, Ogunkolade BW, Hales CN, Boucher BJ: Vitamin D receptor gene polymorphisms influence insulin secretion in Bangladeshi Asians[J]. DIABETES-NEW YORK 1998, 47:688-690.

20. Arunabh S, Pollack S, Yeh J, Aloia JF: Body fat content and 25-hydroxyvitamin D levels in healthy women[J]. J Clin Endocrinol Metab 2003, 88(1):157-161.

21. Forman JP, Giovannucci E, Holmes MD, Bischoff-Ferrari HA, Tworoger SS, Willett WC, Curhan GC: Plasma 25-hydroxyvitamin D levels and risk of incident hypertension[J]. Hypertension 2007, 49(5):1063-1069.
22. Liu E, McKeown N, Pittas AG, Meigs JB, Economos CD, Booth SL, Jacques PF: Predicted 25-hydroxyvitamin $D$ score and change in fasting plasma glucose in the Framingham offspring study[J]. Eur J Clin Nutr 2011, 66(1):139-141.

23. Liu E, Meigs JB, Pittas AG, Economos CD, McKeown NM, Booth SL, Jacques PF: Predicted 25-hydroxyvitamin $\mathrm{D}$ score and incident type 2 diabetes in the Framingham Offspring Study[J]. Am J Clin Nutr 2010, 91(6):1627-1633.

24. Filus A, Trzmiel A, Kuliczkowska-Plaksej J, Tworowska U, Jedrzejuk D, Milewicz A, Medraś M: Relationship between vitamin D receptor Bsml and Fokl polymorphisms and anthropometric and biochemical parameters describing metabolic syndrome[J]. Aging Male 2008, 11(3):134-139.

25. Schuch NJ, Garcia VC, Vivolo SR, Martini LA: Relationship between Vitamin D Receptor gene polymorphisms and the components of metabolic syndrome[J]. Nutr J 2013, 12:96

26. Asian PJ: B-cell lymphoma 2 rs 17757541 C > G polymorphism was associated with an increased risk of gastric cardiac adenocarcinoma in a Chinese population[J]. Asian Pacific J Cancer Prev 2013, 14(7):4301-4306.

27. Tanaka T, Ngwa JS, van Rooij FJ, Zillikens MC, Wojczynski MK, Frazier-Wood AC, Houston DK, Kanoni S, Lemaitre RN, Luan J, Mikkilä V, Renstrom F, Sonestedt E, Zhao JH, Chu AY, Qi L, Chasman DI, de Oliveira Otto MC, Dhurandhar EJ, Feitosa MF, Johansson I, Khaw KT, Lohman KK, Manichaikul A, McKeown NM, Mozaffarian D, Singleton A, Stirrups K, Viikari J, Ye Z, et al: Genome-wide meta-analysis of observational studies shows common genetic variants associated with macronutrient intake[J]. Am J Clin Nutr 2013, 97(6):1395-1402.

28. Zhang YH, Xu Q, Zhao Z, Wu J, Liu WX, Wang H, Jin L, Wang JC: Polymorphism rs7214723 in CAMKK1 and lung cancer risk in Chinese population[J]. Tumor Biol 2013, 1-6.

29. Ye W-Z, Reis AF, Dubois-Laforgue D, Bellanné-Chantelot C, Timsit J, Velho G: Vitamin $D$ receptor gene polymorphisms are associated with obesity in type 2 diabetic subjects with early age of onset[J]. Eur J Endocrinol 2001, 145(2):181-186.

30. Tworowska-Bardzinska U, Lwow F, Kubicka E, Łaczmański Ł, Jedzrzejuk D, Dunajska $K$, Milewicz A: The vitamin D receptor gene Bsm I polymorphism is not associated with anthropometric and biochemical parameters describing metabolic syndrome in postmenopausal women [J]. Gynecol Endocrinol 2008, 24(9):514-518.

31. Malecki M, Frey J, Moczulski D, Klupa T, Kozek E, Sieradzki J: Vitamin D receptor gene polymorphisms and association with type 2 diabetes mellitus in a Polish population[J]. Exp Clin Endocrinol Diab 2003, 111(08):505-509.

32. Valdivielso JM, Fernandez E: Vitamin D receptor polymorphisms and diseases[J]. Clin Chim Acta 2006, 371(1):1-12.

33. Laakso M, Sarlund H, Mykkänen L: Insulin resistance is associated with lipid and lipoprotein abnormalities in subjects with varying degrees of glucose tolerance[J]. Arterioscler Thromb Vasc Biol 1990, 10(2):223-231.

34. West KM, Ahuja M, Bennett PH, Czyzyk A, De Acosta OM, Fuller JH, Grab B, Grabauskas V, Jarrett RJ, Kosaka K: The role of circulating glucose and triglyceride concentrations and their interactions with other - risk factors\| as determinants of arterial disease in nine diabetic population samples from the WHO multinational study[J]. Diabetes Care 1983, 6(4):361-369.

35. Wang TJ, Zhang F, Richards JB, Kestenbaum B, van Meurs JB, Berry D, Kiel DP, Streeten EA, Ohlsson C, Koller DL, Peltonen L, Cooper JD, O'Reilly PF, Houston DK, Glazer NL, Vandenput L, Peacock M, Shi J, Rivadeneira F, McCarthy MI, Anneli P, de Boer IH, Mangino M, Kato B, Smyth DJ, Booth SL, Jacques PF, Burke GL, Goodarzi M, Cheung $\mathrm{CL}$, et al: Common genetic determinants of vitamin $D$ insufficiency: a genome-wide association study[J]. Lancet 2010, 376(9736):180-188.

36. Ahn J, Yu K, Stolzenberg-Solomon R, Simon KC, McCullough ML, Gallicchio L, Jacobs EJ, Ascherio A, Helzlsouer K, Jacobs KB, Li Q, Weinstein SJ, Purdue M, Virtamo J, Horst R, Wheeler W, Chanock S, Hunter DJ, Hayes RB, Kraft P, Albanes D: Genome-wide association study of circulating vitamin D levels[J]. Hum Mol Genet 2010, 19(13):2739-2745.

37. Goltzman D: Vitamin D, action[J]. Ann N Y Acad Sci 2010, 1192(1):145-152.

38. Zeitz U, Weber K, Soegiarto DW, Wolf E, Balling R, Erben RG: Impaired insulin secretory capacity in mice lacking a functional vitamin $D$ receptor [J]. FASEB J 2003, 17(3):509-511.

doi:10.1186/1476-511X-13-129

Cite this article as: Zhao et al: Association of vitamin D receptor gene polymorphisms with metabolic syndrome: a case-control design of population-based cross-sectional study in North China. Lipids in Health and Disease 2014 13:129. 